\title{
超音波平面研削用カップ砥石の開発*
}

\section{CAE システムによる最適設計一一}

\author{
清 水弘幸** 竹内芳 美***
}

Development of a Cupped Diamond Wheel for Ultrasonic Surface Grinding

- CAE Approach to the Optimal Design of the Wheel-

Hiroyuki Shimizu and Yoshimi Takeuchi

The study deals with the development of a new cupped diamond wheel used in ultrasonic surface grinding of brittle materials such as fine ceramics. The wheel has a larger diameter and higher stiffness than the usual wheel, therefore it allows the user to grind brittle materials efficiently and precisely. By using the CAE system which has been developed to design an optimal high-intensity ultrasonic system, the wheel is designed optimally so as to resonate in half-wave at the resonance frequency of an employed ultrasonic vibrator. Then, the wheel is produced on the basis of the designed values, its vibrational properties are measured, and the experiments using it in ultrasonic surface grinding are carried out. As a result, the reasonabilities of the designed values are proved, and the potentiality of the wheel is confirmed.

Key words: cupped diamond wheel, ultrasonic surface grinding, brittle material, CAE, optimal design

\section{1. ま え がき}

硬ぜい材であるセラミックスの加工は，一般にダイ ヤモンド砥石を用いた研削により行われている，この とき超音波振動を与える超音波研削を行らと, 研削特 性を良好にし高能率で高精度な加工を可能とすること が報告されている(1) - 5). これらの報告中, 超音波平面 研削加工に関する研究は，筆者らの知る限り，植松ら の報告5) しか見当たらない，この報告で使用している ダイヤモンド砥石製の平面研削用カップ砥石は，通常 の研削（超音波振動を用いない研削）で使用するカッ プ砥石に比べて，かなり直径の小さい小型なものであ る.小型なカップ砥石であると，それを超音波振動系 に付加された集中質量とみなすことがでさ，超音波振 動系を棒の縦振動方程式に基づいて比較的容易に実現 することができる. しかし，セラミックスの超音波平 面研削をより高能率に行抢うとするときには，通常の 研削で用いられている直径の大きい大型なカップ砥石 を使用する必要がある.このよらな大型な通常研削用 カップ砥石になると，それ自身を集中質量と見なすこ

* 原稿受付 平成 4 年 4 月 13 日

** 正会員 帝京技術科学大学情報学部 (市原市潤井戸大 谷 2289)

*** 正会員 電気通信大学電気通信学部（調布市調布ヶ丘 1-5-1)
とができず，棒の繸振動方程式に基づく超音波振動系 の実現は不可能となる，そこで，七ラミックスの超音 波平面研削加工をより高能率に行らためには，通常研 削用のカップ砥石と同等の直径を有し，超音波研削に 適した新しい形状と構造のカップ砥石の実現が望まれ る.このような新しいカップ砥石は，その形状の複雑 さから棒の縦振動方程式では実現できず，有限要素法 によってのみ実現されることができる、

本研究は，七ラミックスの超音波平面研削加工をよ り高能率化でさる新しい超音波平面研削用カップ砥石 を開発することを目的とし，まず，それ自身が半波長 共振する超音波振動体であり，かつ剛性が高く直径の 大きい新しいカップ砥石の構造と形状を考案するそそ して，既に開発した有限要素法に基づく強力超音波振 動系の最適設計用 $\mathrm{CAE}$ システム ${ }^{6)}$ を用いて, 考案し たカップ砥石の最適設計を行う。そして，実際にその カップ砥石を用いた超音波振動系を実現し，その振動 特性を測定する.それから，実現した超音波振動系を 用いて，セラミックスの平面研削加工実験を行い，考 案したカップ砥石の可能性を検討していく.

\section{2. 超音波平面研削用カップ砥石の設計}

\section{1 形状寸法}

セラミックスの平面を超音波振動を与えないで正面 


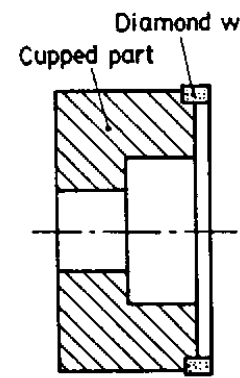

(a) A usual type

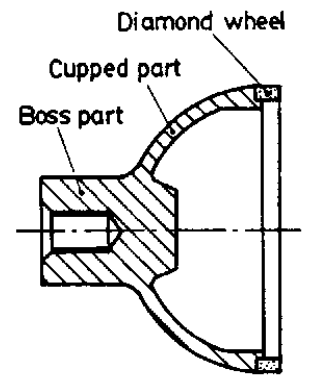

(b) A new type

Fig. 1 Shape and structure of two cupped diamond wheels

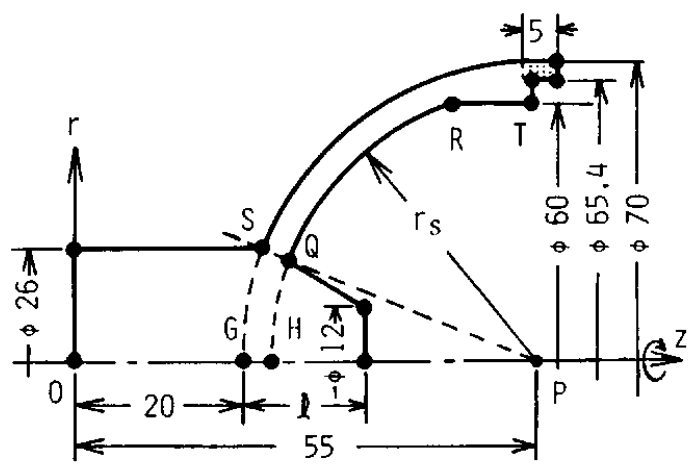

Fig. 2 Geometry of a new cupped diamond wheel for ultrasonic grinding

研削加工する従来の通常研削用カップ砥石の断面形状 と構造を図 1 (a) に示す。このカップ䃨石は、リング 状のダイヤモンド䃨石とそれを取り付ける円筒状の カップ部から構成されており, 通常, 50 〜 $200 \mathrm{~mm}$ の 外径のものが使用されている. 一方，これまでの超音 波平面研削の研究 ${ }^{5)}$ 中で使用しているカップ砥石の外 径は $30 \mathrm{~mm}$ と小さく, 通常の外径のカップ砥石を使 用するとなると，ま齐がきで述べたよらにカップ砥石 を集中質量とみなすことができず超音波振動系を実現 することができなくなる，そこで，図1（b）に示すよ らな形状と構造のカップ䂠石を考案した。このカップ 䃨石は，リング状のダイヤモンド䃨石をろう付け結合 する半球殻状のカップ部と，超音波振動子とねじ結合 するボス部とにより構成され，全体で半波長共振し， 軸長が短くて㓮性の高いものである. 以後, この考案 したカップ砥石を超音波平面研削用カップ砥石と呼ぶ ことにする．その形状寸法を図 2 に示すが，図中の - 印は形状の特徵を表す点である. 本研究では, 最 初の試みとして, 外径 $70 \mathrm{~mm}$, 内径 $65.4 \mathrm{~mm}$, 幅 5 $\mathrm{mm}$ の中型のリング状ダイヤモンド砥石を使用するこ とにする．使用する砥石の形状が決まるとカップ部の

外径が決まる。また，ボス部の形状寸法を，用いる超 音波振動子（共振振動数 $f_{0}=16.36 \mathrm{kHz}$ ) とのねじ結 合を考虑して図 2 のよ5に決める．結局，超音波平面 研削用カップ砥石の形状を決定するパラメータは, カップ部の内径 $r_{\mathrm{s}}$ と, ボス部延長の $l の 2$ 変数とな る. 次に, この $2 つ の$ 形状パラメータを変化して, 望 ましい超音波平面研削用カップ砥石を設計していく，

\section{$2.2 \mathrm{CAE}$ システムによる最適設計 ${ }^{6}$}

まず最初に，設計に使用するCAE システムの設計 概念を簡単に説明する。いま，形状寸法などの設計諸 元よりなる集合を $D$, 固有振動数などの属性諸元よ りなる集合を $P$ とすると, $P$ の各要素 $P_{i}$ は,

$$
P_{i}=f_{\mathrm{ci}}(D)
$$

と求められる.ここで，記号 $f_{\mathrm{c}}$ は集合 $D$ の各要素す べてを引き数とする有限要素法による強力超音波振動 系の振動解析専用プログラムでの演算を意味する7). いま，制約仕様と目標仕様が与えられたときの設計を 考える. 制約仕様は, 設計諸元と属性諸元とへの制約 があるので, 制約諸元からなる集合を $C=\left[C_{1}, C_{2}\right]$ と すると，

$$
C_{1} \cong D, \quad C_{2} \cong P
$$

なる関係が成立し，制約仕様を

$$
C_{m} \leqq \bar{C}_{m} \quad(m=1,2)
$$

と表すことができる.ここで，集合 $\bar{C}_{m}$ は，集合 $C_{m}$ の各要素に対して制約を定める.上限值よりなる集合で ある. 式（3）を満たす集合 $C_{m}$ の領域を，一般に制約 領域と呼んでいる.

一方, 目標仕様については, 本研究で扱ら強力超音 波振動系の設計に対しては，振動系の性能を設計目標 にする場合が王倒的に多い。この振動系の性能を表す 諸元は，属性諸元に含まれるので目標仕様の定式化は 次のように表現できる.すなわち，目標諸元よりなる 集合を $A$ とすると,

$$
A \subseteq P
$$

なる関係が成立し，集合 $A$ の各要素を $A_{i}$ とすると き, 目標仕様を

$$
f_{\mathrm{C} i}\left(D_{0}\right)=\operatorname{Min}\left[A_{i}\right]
$$

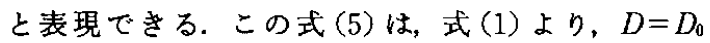
のとさ $A_{i}$ を最小（以下で，最小を最大と考えてる同 じである）にでき，目標値を $A_{i}$ の最小に批いたとき $D_{0}$ が最適設計値であることを意味する.

本研究で用いる既に開発した CAE システムの基本 的概念は，式 (3) の制約条件下で式 (5)の方程式を満 たす解 $D_{0}$ を, 有限要素法専用プログラムの演算結果 から，一斉探索方式に基つく最適化プログラムによ り，自動的に選択することにある。 


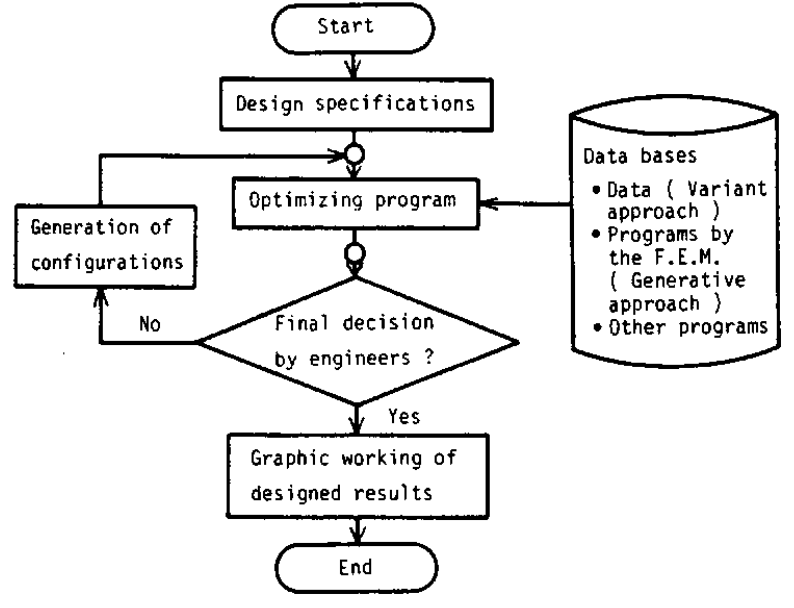

Fig. 3 Flowchart of a CAE system to design an optimal high.intensity ultrasonic system

なおこのような設計概念に基ついて既に開発した 強力超音波振動系専用の最適設計 $\mathrm{CAE}$ システムのシ ステム構成罒を図 3 に示すが，その詳細については， 既報の文献 ${ }^{6)}$ を参照して頂きたい。

さて，本研究では設計目標を次のように決定した： （1）超音波平面研削用カップ砥石振動体の第一次共振 振動数が使用する超音波振動子の $16.36 \mathrm{kHz}$ 近傍に あること，（2）超音波の衝撃破砕を原理とする高能率 除去加工を使用するため, 砥石先端の振動変位成分が 軸方向（z方向）成分になること，である.

このとき，各諸元集合を次のように定義した.

$$
\begin{aligned}
& D=\left[r_{\mathrm{s}}, l\right] \\
& P=\left[f_{1}, V_{z}, V_{r}\right]
\end{aligned}
$$

ここで, $r_{\mathrm{s}}, l$; 各々図 2 に示す設計変数, $f_{1}$; 第一次 モードの共振振動数, $V_{z}, V_{r}$ ；カップ外周での基準化
された $z$ 拈よび $r$ 方向変位成分である。ぬた， 制約諸元集合 $C$ を,

$$
C=\left[r, r_{\mathrm{s}}, l, \text { 材質, } f_{\mathrm{l}}, V_{z}, V_{r}\right]
$$

と定義する.ここで， $r$ はカップ部の外形であ る. 実際の上限值を定めた式 (3) に相当する制 約条件式は,

$$
\begin{aligned}
C_{1}= & {\left[r=35 \mathrm{~mm}, .20 \mathrm{~mm}<r_{\mathrm{s}}<35 \mathrm{~mm},\right.} \\
& 0 \mathrm{~mm}<l<30 \mathrm{~mm}, \text { 材質 }=\text { 銅 }], \\
C_{2}= & {\left[15.86 \mathrm{kHz}<f_{1}<16.86 \mathrm{kHz},\right.} \\
& \left.0.5<V_{z}, V_{r}<0.2\right]
\end{aligned}
$$

である.さらに，目標諸元集合 $A$ を，

$$
A=\left[\left|f_{1}-16.36 \mathrm{kHz}\right|,\left|V_{r}\right|\right]
$$

と定義する.そして，実際にこのCAEシステ ム中のジェラティブアプローチを働かせ,

$$
f_{\mathrm{C}}\left(D_{0}\right)=\operatorname{Min}\left[\left|f_{1}-16.36 \mathrm{kHz}\right|,\left|V_{\mathrm{r}}\right|\right]
$$

を満たす最適設計値 $D_{0}$ を求めた. その結果として, 式 (11) を満足する最適設計值として $r_{\mathrm{s}}=32 \mathrm{~mm}$, $l=18 \mathrm{~mm}$ なる値を自動的に得た.

\section{3 形状パラメータの性留}

使用したCAEシステムは，通常使用時，最適設計 結果のみを出力するが, 必要に応じて途中の設計経過 もみることができる.そこで, 形状パラメータ $r_{\mathrm{s}}$ と $l$ が，共振振動数及び䃨石の加工面の振動変位成分 $V_{z}, V_{r}$ にどのような影響を与えているのかを調べて みる、ま寸゙, 形状パラメータ $l=35-r_{\mathrm{s}}(\mathrm{mm})$ のとき, すなわちカップ部の内面が図 2 の点 $\mathrm{R}, \mathrm{Q}, \mathrm{H}$ を通る球 面のとき，形状パラメー夕 $r_{\mathrm{s}}$ を変化させて得られた 結果を図 4 (a) に示す。次に，形状パラメータ $r_{\mathrm{s}}=32$ $\mathrm{mm}$ と一定にし, 形状パラメータ $l$ を変化させて得ら

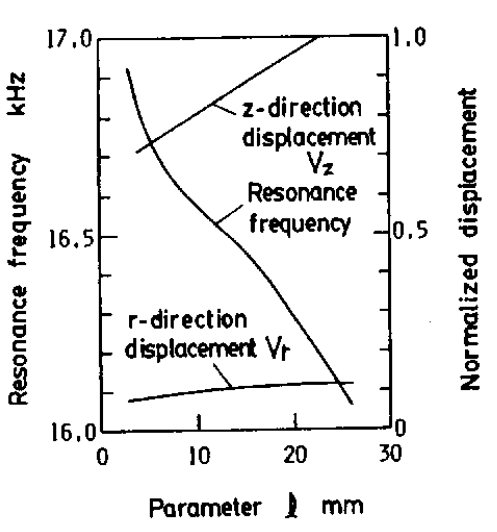

(b) Effect of the paraseter $l$

(a) Effect of the paraseter $r$ s

Fig. 4 Effects of two geometrical parameters $r_{\mathrm{s}}$ and $l$ on vibrational properties of a new cupped diamond wheel 


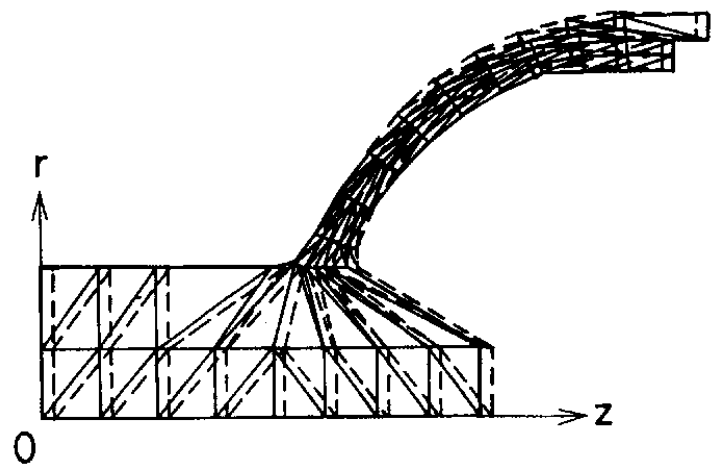

Fig. 5 Mode shape in half-wave resonance of a new cupped diamond wheel designed optimally

れた結果を図 4 (b) に示す。これらの図中の 2 つの振 動変位成分は, 超音波平面研削用カップ砥石のボス部 中心（図 2 の点 0 ）の $z$ 方向振動変位成分で基準化 した值である. 図4(a)より形状パラメータ $r_{\mathrm{s}}$ が増 加すると, 共振振動数と $r$ 万向変位成分が大きく減 少しているが， $z$ 方向振動变位成分はそれ程でもない ことがわかる. 2.2 項で述べたよらに, 最適値として $r_{\mathrm{s}}=32 \mathrm{~mm}$ を決定しているが, 図4(a)の $r_{\mathrm{s}}=32$ $\mathrm{mm}$ をると, $r$ 方向振動変位成分が極めて小さく, $z$ 方向振動变位成分のみが存在することがわかる.こ れは，2.2 項で述べた設計目標の事項 (2) を満足す る. しかし, 共振振動数は $18 \mathrm{kHz}$ 付近にあり, 事項 （1）を満足しない.

次に，因 4 (b) をみると，形状パラメータlの增加 に対して, 共振振動数は堿少し, $z$ 方向振動変位は増 加するが, $r$ 方向振動変位は变化せす極めて小さい值 をとることがわかる. 2.2 項で述べた最適値 $l=18$ $\mathrm{mm}$ をみると，共振振動数は $16.36 \mathrm{kHz}$ となり，ま た, $z$ 方向振動変位成分のみに近い状態となり, 設計 目標を達成していることがわかる. 図 4 (a)，(b)よ り, 形状バラメータ $r_{\mathrm{s}}$ は主に振動変位成分の設計に, 形状パラメータlは主に共振振動数の調整に役立って いることがわかる.

\section{4 設計された振動モードの形}

2.2 項で最適設計された超音波平面研削用カップ砥 石の半波長共振での振動モードの形を図 5 に波線で示 す. 実線は有限要素分割モデルを表す。同図をみる 之, 砥石先端の加工面は $z$ 万向にのみ変位し $r$ 方向 に変位しないこと, 及びその変位方向はボス部の結合 端面の変位方向と反対 $\left(180^{\circ}\right.$ の位相差) であり振動 節がボス部とカップ部の結合位置（図2中の線分 SQ）よりややカッブ部寄りの位置に存在し全体で半 波長共振を起こしていることがわかる．また，形状パ

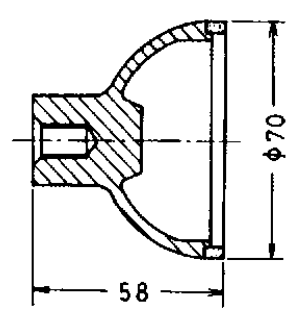

(a) A new type by the CAE appraach

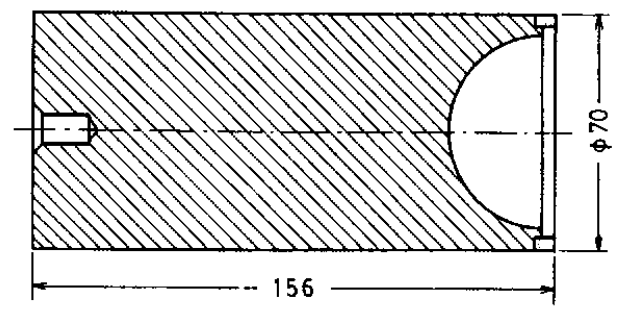

(b) A bar type by the conventional one-dimensional approach

Fig. 6 Geometrical comparison between two types of diamond wheels for ultrasonic grinding designed by means of two approaches

ラメータ $l$ を含むボス部は剛体運動をなし, 形状パラ メータlの変化が付加質量として超音波平面研削用 カップ砥石の共振振動数を調整している（図 4 (b)に 示す）ことがわかる. このように, 得られた振動モー ドの形からす，最適設計値が妥当な值であることがわ かる.

\section{5 䋖振動方程式による設計結果との比較}

まえがきでも述べたように，従采の通常研削用カッ プ砥石を用いる超音波振動系は, 棒の綎振動方程式に 基づいて設計されることができないしかし，リング 状のダイヤモンド砥石を軸方向に均一に振動させるだ けなら, 超音波振動系を棒の縦振動方程式を用いるこ とにより設計できる、ただし，碈石の外形が大きくな ると，すなわら棒が太くなると縦方向（ 成分のはか飞径方向 ( $r$ 方向) 振動成分が重睴して, 縦振動方程式より求めた共振振動数の值が真の値より 低くなる．ちなみに，この方程式が成立する棒の形状 範曲を述べると, 棒の直径を $d$, 波長を入とすると き， $d / \lambda<1 / 4$ である

さて，CAEシステムにより最適設計された超音波 平面研削用カップ砥石の形状を図 6 (a) に，また，棒 の縦振動方程式により求めた半波長共振の棒状のカッ プ砥石を図6(b)に示す.同一の共振振動数 16.36 $\mathrm{kHz}$ に対して, 超音波平面研削用カッブ砥石の軸長 は棒状のものの約 $1 / 3$ に短くなることがわかる. 軸長 が長いと, 研削加工時の横荷重に対する剛性が低くな 


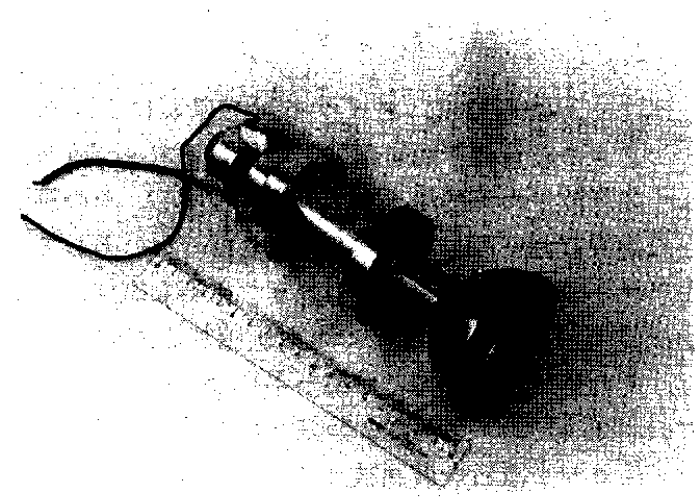

Fig. 7 High-intensity ultrasonic system produced for surface grinding

り，砥石の逃げを生じたり早い横送りをかけることが できなくなる，よって，棒の綐振動方程式により設計 した棒状のカップ砥石は平面研削に使用できないこと がわかる，また，逆に，超音波平面研削用カップ砥石 は, 軸長が短く, 横荷重及び偏心綎荷重に対して剛性 が高く, 平面研削に適することがわかる.

\section{3. 超音波平面研削用カップ砥石の振動測定}

前節で CAE システムにより設計された最適設計値 が妥当な値であることを，計算値に基づいて説明し た．本節では，更に実験によりその妥当性を調べる。

\section{1 超音波振動系の試作}

得られた最適設計値に基づいて, 超音波平面研削用 カップ砥石を含む超音波振動系を図７に示すよ5に試 作した，超音波平面研削用カップ砥石に結合する超音 波振動子は, ボルト締めランジュバン型振動子とコニ カル形固体ホーンを一体化したもので, その共振振動 数は $16.36 \mathrm{kHz}$ である.この試作した振動系の共振 振動数の実測值は $16.07 \mathrm{kHz}$ であり, 設計値とよく

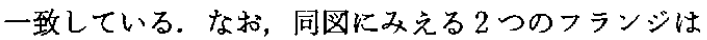
支持用のるのである.

\section{2 ホログラフィ技術による振動測定}

超音波平面研削用カップ碈石に近い方のフランジ支 持体を支持し，半波長共振を生じさせたときの超音波 平面研削用カップ䃨石の振動モードの形をホログラ フィ技術の実時間ストロボ法により撮影した. 图 8 は, 入力パワーが $0.5 \mathrm{~W}$ のとき撮影されたホログラ 么の再生像を示す，写真の左側は超音波平面研削用 カップ砥石の側面であり，主として $r$ 方向振動成分 が撮影されている．また，写真の右側はこの振動体の 正面であり，主として $z$ 方向振動変位成分が撮影さ れている．同図右側にみえるきれいな同心円状のしま

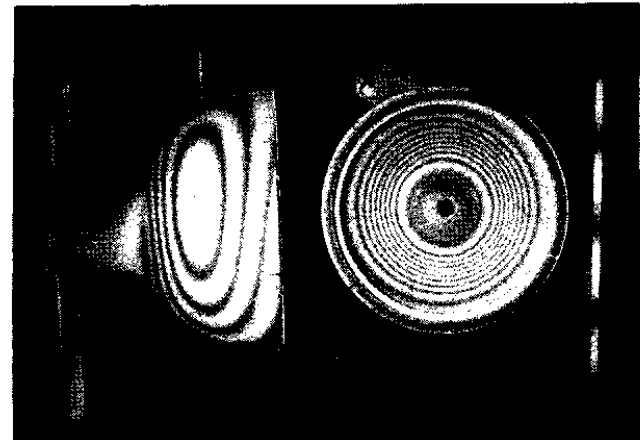

Fig. 8 Hologram reconstruction of a new cupped diamond wheel in half-wave resonance

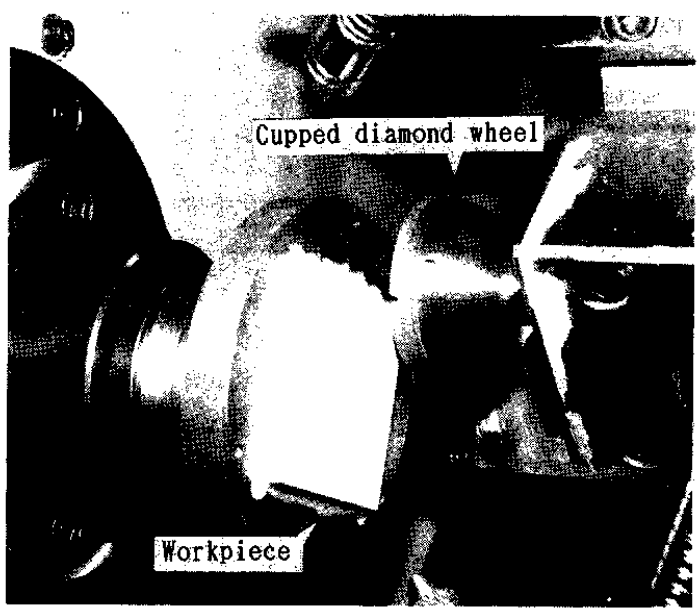

Fig. 9 View of an experimental apparatus for ultra. sonic surface grinding

模様は，試作した超音波平面研削用カップ砥石が設計 値通りの軸対称共振モードで共振していることを示 す.このことは, CAEシステムで有限要素として軸 対称 3 角りング要素を使用したことが正しいことを実 証する.

\section{4. 超音波平面研削加工实験}

本節では，実際に試作した超音波平面研削用カップ 砥石を用いてセラミックスの平面を研削加工する超音 波平面研削加工実験を行う。

\section{1 実験装置と方法}

$\mathrm{NC}$ 旋盤を使用した実験装置の写真を図 9 に示す。 主軸にセラミックス材を固定し，刃物台に試作した超 音波掁動系を取り付けて，セラミックスを回転させな がら超音波平面研削用カップ砥石を横送りして超音波 正面研削加工を行う，実験は，切込及深さを変化した とさの表面粗さの变化を調べる，このときの実験条件 を表 1 に示寸。被加工物としてのセラミックスにはア 
Table 1 Ultrasonic grinding conditions

\begin{tabular}{l|l}
\hline Workpiece & Alumina $\mathrm{A} 480\left(\mathrm{Al}_{2} \mathrm{O}_{3} ; 99.8 \%\right)$ \\
\hline Wheel & $\begin{array}{l}\text { An iron bonded diamond wheel } \\
\text { Grain size : \# } 100 / 120, \text { concentration } ; 100\end{array}$ \\
\hline $\begin{array}{l}\text { Ultrasonic } \\
\text { system }\end{array}$ & $\begin{array}{l}\text { A cupped diamond wheel } \\
\text { Resonance frequency }: 16.11 \mathrm{kHz} \\
\text { Input power }: 20 \mathrm{~W} \\
\text { Amplitude (no-load) }: 10 \mu \mathrm{m}\end{array}$ \\
\hline $\begin{array}{l}\text { Grinding } \\
\text { condition }\end{array}$ & $\begin{array}{l}\text { Peripheral speed }: 1600-2100 \mathrm{~mm} / \mathrm{s} \\
\text { Rate of feed }: 50 \mu \mathrm{m} / \mathrm{rev} \\
\text { Depth of cut : } 2-50 \mu \mathrm{m}\end{array}$ \\
\hline $\begin{array}{l}\text { Cutting } \\
\text { fluid }\end{array}$ & Wet cutting (solution type) \\
\hline
\end{tabular}

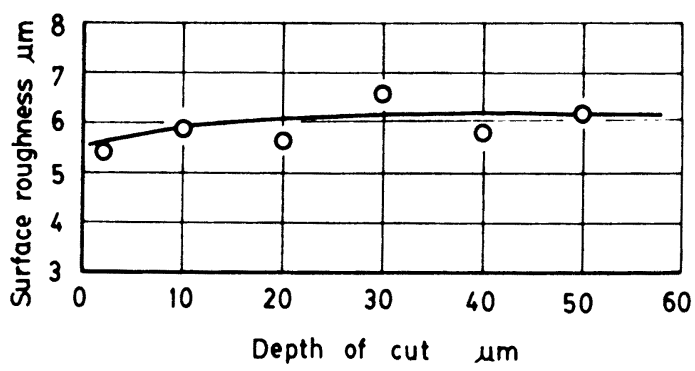

Fig. 10 Relationship between depth of cut and surface roughness

ルミナ系A 480 材（京セラ社製）を，また，砥石に は超音波振動をよく伝達する鋳鉄ファイバボンドダイ ヤモンド砥石を使用する。

\section{2 実 験 結 果}

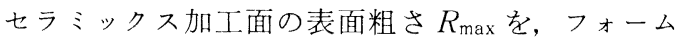
タリサーフ（ランクテーラホブソン社製）を用いて測 定した. 多くの測定結果から, 切込み深さに対する表 面粗さ $R_{\max }$ の変化を求めたものを図 10 に示す。こ の図より切込み深さが増加しても表面粗さ $R_{\max }$ はほ とんど変化しないことがわかる. この実験中に試作し たカップ砥石には異常が生じなく，このカップ砥石の 可能性を確認することができた。今後, 加工能率や目 立て寿命などの必要な事項をさらに検討して行く予定 である.

\section{5. むす び}

以上，本研究では，ダイヤモンド砥石によるセラ ミックスの超音波平面研削加工に用いるカップ砥石と して超音波平面研削用カップ砥石を提案し，その設計 を最適設計用 CAE システムにより行った. そして, 得られた設計値に基づきこのカップ砥石を試作し，振 動測定実験を行うとともに平面研削加工実験を行っ た. その結果，次のことが明らかになった。

（1） CAE システムにより望なれる超音波平面研削 用カップ砥石を最適設計することができた。

（2）振動特性の設計值と垁测优はよく一致し，設 計值の妥当性を寒験的に証明することができた。

（3）超音波平面研削拥カッブ砥不の可能性を確か めることができた。

今後, 開発した超音波平面研削用カップ碈不を用い たより詳細な平面研削加亡楶験を行らとともに，同心 円状溝研削加工への応用を研究して行く予定である.

終わりに，本研究を遂行するに当たり多大なご協力 を頂いた，(株)超音波厂業の関广芳文氏，武内彰氏， (株) ニコンの木村景一民（現(株)ソニー），川口健一 氏，及び(株)富士写真光機の宇朋川哲夫氏に対して深 く感謝の意を表します。

\section{参 考 文 献}

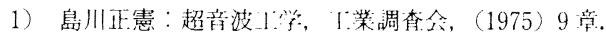

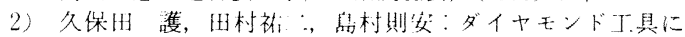
よる超音波加 T.，精密機械，42，3（1976）197.

3）海野邦昭，西村…人，皆川明，䈏森紘：超音波研削

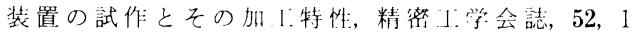
(1986) 107 .

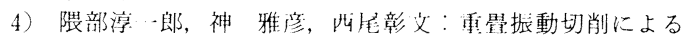

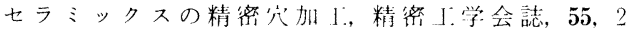
(1989) 366.

5）植松哲太郎汪か：マシニングセンタによる硬脆材料の研 削加工, 昭和 63 年度精密.. 学会春季大会学術講演会講演 論文集, (1988) 509.

6）清水弘幸，传时登志夫：強力超等波挀動采専用の最適設 計システムの開発, 精泌「学会誌, 54, 5 (1988) 983.

7) 沖野教郎：自動設計の方法淪, 養賢堂, (1982) 第 1 章.

8）清水弘幸, 佐田登志犬：強力超省波振動系の拢動解析法 打よびその検証，精密「学会誌，54，1（1988）177. 